\title{
Preparedness of companies for digital transformation and creating a competitive advantage in the age of Industry 4.0
}

\author{
Anna ADAMIK \\ Faculty of Management and Production Engineering \\ Department of Management, Lodz University of Technology, Poland \\ anna.adamik@p.lodz.pl \\ Michał NOWICKI \\ Faculty of Management and Production Engineering \\ Department of Management, Lodz University of Technology, Poland \\ michal.nowicki@p.lodz.pl
}

\begin{abstract}
One of the biggest challenges that organizations are facing today is finding the proper way to shape competitive advantages in the age of Industry 4.0. This digital revolution forces companies to face specific challenges. The main purpose of this paper is to identify key requirements for the creation of a competitive advantage in the age of Industry 4.0 [CA. 4.0] The second purpose is to evaluate the level of organizations' preparedness for Digital Transformation [DX]. Studies based on a literature review describe requirements for organizations functioning in the age of Industry 4.0, especially in the area of DX and exploitation of Virtualization [V\&DX].
\end{abstract}

Keywords: competitive advantage, methods of creating a competitive advantage, digital transformation, Industry 4.0., competitive advantage 4.0.

\section{Introduction}

One of the biggest challenges that organizations are facing today is finding the proper way to shape competitive advantages in the age of Industry 4.0. It is a condition of their longterm survival in the market. The main purpose of this paper is to identify key requirements for the creation of a competitive advantage in the age of Industry 4.0 [CA. 4.0]. The second purpose is to evaluate the level of preparedness for digital transformation [DX] among Polish SMEs. In order to do so, the authors conducted their own empirical research.

The presentation of the results of the empirical research has been preceded by the presentation of theoretical considerations concerning 1) the nature and background of the phenomenon of shaping CA 4.0, and 2) the essence and background of the phenomenon of V\&DX along with its importance for the creation of CA 4.0.

\section{Literature review}

A competitive advantage [CA] is a central idea in the strategic management literature and a key element in the process of creating competitiveness of all types of businesses. The result of this process, i.e. the competitiveness of a given entity, is a strategic feature from the point of view of its long-term functioning and development. Due to its nature, its components include efficiency, dynamism and flexibility of the studied business. It is created in processes of exchange between a company and its environment. However, it is characteristic for the organization \& management science literature that the essence of CA creation is still variously defined (So what is ... 2013), and what is more, knowledge about it is still developing (Catch me ... 2016). In most cases, it is pointed out that an organization's

DOI: $10.2478 /$ picbe-2018-0003 
ability for CA creation is related to its ability of skillfully distancing and distinguishing from competitors, especially by building unique relationships with environment (Porter, 2008; Rao, 2016). It is increasingly often indicated that the ability to create a [CA] is connected with a schematic, bold thinking, an extreme change in the manner business is conducted, operational speed, innovative ideas and finding revolutionary solutions (Chakravorti, 2010; Elahi, 2013). All the above-presented considerations lead to the conclusion that it is a phenomenon increasingly difficult to sustain (Salem 2016, Shams 2016), design and effectively implement (Vecchiato, 2015; Parsons, 2015). [CA] should be seen as a given company's ability to develop, and later on to control a special and peculiar type of resources and skills which allows it to create and implement strategies that improve its performance and efficiency (Barney, Hesterly, 2006). [CA] is its ability to consciously identify, deploy, develop, protect and enjoy the benefits of such unique resources and competences which are wanted and valued by the market, and which are not available to the same extent to other competitors (Adamik, 2008).

Studies have shown that today the ability to combine different types of resources and skills is a particularly important source of [CA]. Creating unique and competitive combinations in this regard increases chances of long-term market success (Ferrier, Wiltbank, 2010). The ability to identify, shape and develop exceptional competences within a company is important along with the ability to mobilize the necessary resources and skills located outside the company (Adamik, 2016). For this purpose, the mastery of three essential activities is necessary: dynamic specialization, connectivity and the creation of the business potential in clusters of many entities. The greatest results are achieved by the deliberate use of global business and technological structures that may go beyond the boundaries of one enterprise and reach the potential of companies all around the world (Kiron, Shockley, 2011). Thus, two core pillars of the process of CA formation emerge: the internal capacity of a company and its environment (including its partners). For their optimal compatibility and use nowadays, deliberate implementation of appropriately selected and advanced new technologies, promoting inter-organizational cooperation and relationships developing knowledge partnering is necessary (Adamik and Flaszewska, 2015).

In order to increase the efficiency of company market operations and to create their CA in age of Industry 4.0, enterprises have to start to identify, recognize and gradually meet requirements. The first step in this process should be the understanding of the specificity and needs of the age of Industry 4.0.

The concept of Industry 4.0. appeared in the literature in the year 2011 (Hermann, Pentek, Otto, 2015; Qin, Liu, Grosvenor 2016). The concept signaled the need for creating the environment in which the digital world and the physical world would be smoothly and fluidly blending. It also pointed to the growing, along with the technical and technological progress, role of cyber-physical systems, robotization and digitalization in the network economy. Additionally, it stressed the opportunities inherent in computerization of manufacturing, dynamic data processing and new technologies supporting the development of this type of organization - the so-called Smart Factories.

All the information indicates that advantages created in the age of Industry 4.0 will be not only intangible advantages, but temporary ones, quickly "overcome" by competitors. 
The CA 4.0 will be more of a "system" of highly advanced technologically and organizationally CAs than a clearly identifiable, singular activity distinguishing a given company. It will be based on the far more developed understanding and meeting of customer needs (Gaub, 2016) with the use of state-of-the-art technologies and virtual reality. Data necessary for enterprises to build CA in the age of Industry 4.0 are summarized in Table1.

Table 1. Algorithm of preparedness to compete in Industry 4.0

\begin{tabular}{|c|c|c|c|c|}
\hline \multicolumn{5}{|c|}{ Parameters of Industry 4.0} \\
\hline Environment & $\begin{array}{l}\text { Key resources and breakthrough } \\
\text { applications }\end{array}$ & $\begin{array}{l}\text { Ways of creating a } \\
\text { competitive advantage }\end{array}$ & Key advantages & $\begin{array}{l}\text { Nature of } \\
\text { dominant } \\
\text { advantages }\end{array}$ \\
\hline $\begin{array}{l}\text { Digital world } \\
\text { smoothly and } \\
\text { fluidly } \\
\text { permeating } \\
\text { physical world }\end{array}$ & $\begin{array}{l}\text { Intangible: competences, functional } \\
\text { systems, attitudes, capabilities } \\
\text { Cyber-physical } \\
\text { robotization } \\
\text { Digitalization; computerization of } \\
\text { manufacturing; dynamic data } \\
\text { processing, new technologies, } \\
\text { Smart Factories, through: } \\
\text { - Autonomous Robots; } \\
\text { - Simulations; } \\
\text { - Vertical/Horizontal } \\
\text { Integrations; } \\
\text { - Industrial Internet of Things (IoT); } \\
\text { - Machine-to-Machine Communication } \\
\text { (M2M); } \\
\text { - Internet of Services, } \\
\text { - Big Data and Analytics; } \\
\text { - Innovative methods of collecting and } \\
\text { processing massive amounts of data, } \\
\text { including Clouds; } \\
\text { - Augmented Reality (AR); } \\
\text { - Virtual Reality (VR); } \\
\text { - Cyber-Physical Systems (CPS), } \\
\text { - Digital Twins, } \\
\text { - Artificial Intelligence, and Neural } \\
\text { Networks; } \\
\text { - Cybersecurity; } \\
\text {-Mass Customization; }\end{array}$ & $\begin{array}{l}\text { Comprehensive and } \\
\text { optimal use of operations } \\
\text { - ICT, interoperability; } \\
\text { dynamic capabilities, system } \\
\text { partnering, knowledge } \\
\text { partnering, } \\
\text { - virtualization; } \\
\text { robotization, modularity; } \\
\text { decentralization; } \\
\text {-real-time assessment of } \\
\text { capabilities; } \\
\text { - service orientation; } \\
\text { - network cooperation; } \\
\text { - smart: networks, machines, } \\
\text { processes, systems, products, } \\
\text { supply chains, factories (post- } \\
\text { reality); } \\
\text { - sharing economy (C2C, B2C, } \\
\text { B2B) }\end{array}$ & $\begin{array}{l}\text { Differentiation, } \\
\text { including: } \\
\text { - resource-based } \\
\text { advantage } \\
\text { - management } \\
\text { advantage } \\
\text { - information } \\
\text { advantage } \\
\text { - relational } \\
\text { advantage } \\
\text { - time advantage } \\
\text { - location } \\
\text { advantage } \\
\\
\text { Offer advantage, } \\
\text { including: } \\
\text { - advantage of } \\
\text { flexibility } \\
\text { - advantage of } \\
\text { availability } \\
\text { - advantage of } \\
\text { digital serialization } \\
\text { - advantage of } \\
\text { digital integration } \\
\text { - advantage of } \\
\text { customization. }\end{array}$ & $\begin{array}{l}\text { Advantages: } \\
\text { - qualitative } \\
\text { - dispersed } \\
\text { - intangible } \\
\text { - unreal } \\
\text { - hidden } \\
\text { - temporary } \\
\text { - impermanent } \\
\text { - unique } \\
\text { - unclear } \\
\text { - internal and } \\
\text { external } \\
\text { - commercial } \\
\text { - synergistic } \\
\text { - potential }\end{array}$ \\
\hline \multicolumn{5}{|c|}{$\begin{array}{l}\text { Step 1. Awareness of Industry } 4.0 \text { requirements } \\
\text { (ability to assess requirements, knowledge of Industry } 4.0, \text { Knowledge - " } K \text { ") }\end{array}$} \\
\hline \multicolumn{5}{|c|}{$\begin{array}{l}\text { Step 2. The level of activity associated with the exploitation of key resources and key advantages of the age of } \\
\text { Industry } 4.0 \\
\text { (level of implementation of Industry } 4.0 \text { tools, Activity - "A") }\end{array}$} \\
\hline \multicolumn{5}{|c|}{$\begin{array}{c}\text { Step 3. Preparedness for Competitive Advantage } 4.0 \\
\text { (the number of areas with more than the average level of implementation of Industry } 4.0 \text { tools, } \\
\text { Competitive Advantage } 4.0-" C A 4.0^{\prime \prime} \text { ) }\end{array}$} \\
\hline \multicolumn{5}{|c|}{$\begin{array}{l}\text { Step 4. Preparedness to compete in the age of Industry } 4.0 \\
\text { (Comprehensive use of Industry } 4.0 \text { tools, Competitiveness in Industry } 4.0-\text { "CI } 4.0^{\prime \prime} \text { ) }\end{array}$} \\
\hline
\end{tabular}

Source: The authors' own research. 
The conducted literature review and the results of empirical studies allow one to assume that the awareness of the specific requirements of the latest industrial revolution is the first step in the process of preparing enterprises to effectively compete in the age of Industry 4.0 [K-Knowledge, Step 1]. Another step is enterprises' activity in the processes of actual exploration of these requirements, preparation for meeting them, and the ultimate implementation of tools typical of Industry 4.0 in operational processes of companies $[A$ Acivity, Step 2]. The transition to the third level of activities indicates that an enterprises copes with the challenges of Industry 4.0 so effectively that one can observe in its operations areas with more than average degree of implementation of solutions associated with the digital world [CA 4.0, Step 3]. They are the seed of a new type of [CA], i.e. [CA 4.0]. When one can observe in a company's business activity long-term, multi-faceted (holistic) and strong involvement in the use of tools specific to Industry 4.0, it is a signal indicating its readiness to compete in this challenging age [CI 4.0- Competitiveness in Industry 4.0, Step 4].

The above-presented steps are the basis to formulate key research hypotheses for the research described in the paper. The following hypotheses were adopted:

- H1: The awareness of, i.e. the ability to identify and assess, the impact of the requirements of Industry 4.0 on a company's business activity indicates the degree of its preparedness to compete in the age of Industry 4.0.

- H2: A company's activity, i.e. the level of implementation of Industry 4.0 tools in its business operations, raises its level of preparedness to compete in the age of Industry 4.0.

- H3: Above-average involvement of a company in the implementation of solutions associated with the digital world raises its level of preparedness to compete in the age of Industry 4.0.

- H4: The comprehensiveness (multidimensional structure) of a company's involvement in the implementation of Industry 4.0 tools raises the level of its preparedness to compete in the age of Industry 4.0.

Virtualization\&Digital Transformation [V\&DX] is closely linked to the revolution Industry 4.0 (Bender M., Willmott P., 2017). The essence of [V\&DX] places a strong emphasis on the integration of digital technologies and business processes, as well as on the implementation of organizational and technological changes, in particular through an increase in the use of digital technology, information and telecommunications on an unprecedented scale (Berman, Bell/IBM, 2011). Importantly, [V\&DX] also means a change in the way planes, i.e. places that are best suited to a given company's individual needs in achieving maximum profits at minimum costs (Cifranic, 2016;Pupavac, et al., 2013; Bellgran, et al., 2013), of business activity are perceived (Audretdch, et al., 2015; Brakman, Garretsen, 2005). A real plane of business activity should be complemented by its virtual counterpart. i.e. the virtual plane of activity. It is interpreted as: embedding, conducting and promoting economic activity on the virtual plane of action, i.e. using the support of innovative, specialized IT/ICT tools and solutions associated with [DX]. The integration of real and virtual plane (Virtualization) is a complex and time-consuming process that includes in its scope a set of actions performed to transform a traditionally functioning company into a virtually operating one. It requires determining new objectives and 
principles of operation for a given company (Kane et al., 2015). These changes should be strongly supported by digitalization, transforming activities and things on the real plane of operation into virtual ones. The implementation of the [DX] approach in practice means, among others (see: Dubois D., 2017; Soon, 2016; Geissbauer et al., 2016):

- ensuring close integration of all business processes and systems,

- implementing changes that enable both the collection of data in various formats and their effective analysis at a time as close to real time as possible,

- increasing the degree of the use of cloud-based solutions and services (Cloud),

- increasing the use of mobile devices and Internet of Things.

The degree DX will increasingly determine in the future possibilities of creating [CA] (Garrison, Wakefield, Kim, 2015; Tsangaris, 2012).The CISCO analysis indicate that (CISCO, 2014):

- by 2018, at least $20 \%$ of employees will use technologies of automatic support both in the implementation of daily duties and in the decision-making process;

- by $2019,10 \%$ of labor resources in countries with the mature market economy will be based on the sharing economy and a network of free agents;

- by 2020 , more than $66 \%$ of companies will double their productivity thanks to DX of their main operational processes.

BCG experts point out that DX will transform the way organizations design, manufacture, operate and service their products and thus (Rüßmann et al., 2015):

- connectivity and integration among parts, machines, and humans will make production systems as much as $30 \%$ faster and $25 \%$ more efficient, and will elevate mass customization to new levels;

- manufacturing will be transformed from single automated cells to fully integrated, automated facilities that communicate with one another and boost flexibility, speed, productivity and quality.

DX has created unique marketplace challenges and opportunities, as organizations must contend with nimble competitors who take advantage of the low barrier to entry that technology provides (Grossman, 2016). The implications of digitalization for revenues, profits and opportunities have a dramatic upside potential (Bughin, et al., 2017). Analyses of McKinsey Digital indicate that the need to build a competitive position based on "DX" stems mainly from expectations regarding the opportunities that this new reality brings (see Figure 1). 


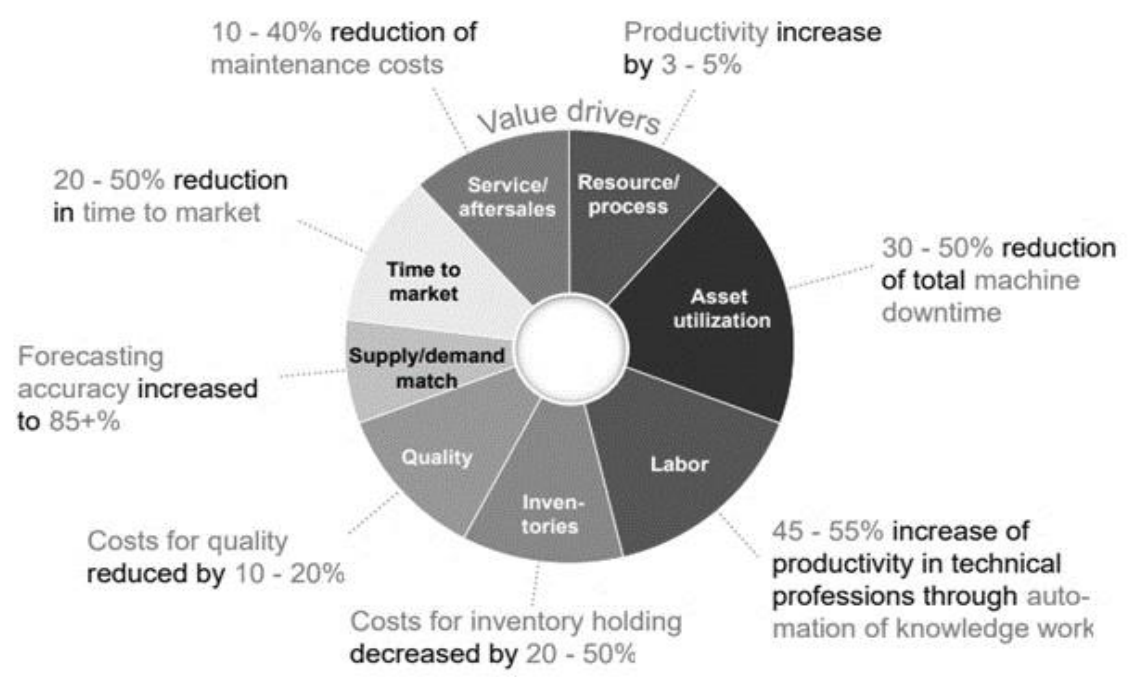

PICBE | 15

Figure 1. V\&DX expected benefits (1)

Source: McKinsey Digital 2015, Industry 4.0 How to navigate digitization of the manufacturing sector.

\section{Methodology}

To empirically illustrate the meaning and level of preparedness of enterprises for [DX] and creating [CA 4.0] in the age of Industry 4.0, a two-stage study among Polish enterprises was conducted in 2017. In the first stage, a pilot study was carried out in five companies of different sizes. It was designed to show the overall approach of businesses to the requirements of Industry 4.0. in its 11 key areas. In the second stage, an in-depth CATI study on a sample of 120 companies in one of the areas of Industry 4.0 was conducted. This study concerned Virtualization of business activity.

In order to conduct a pilot study of maturity of actions and key differences in preparedness for operating in the age of Industry 4.0, one large, global-scale enterprise, three medium and one small-sized companies, illustrating capabilities of organizations of various sizes, were purposefully chosen. For the achievement of the objectives of the research process, a diagnostic questionnaire was used. The questionnaire included queries about the surveyed companies' commitment to solutions specific to Industry 4.0 in 11 areas (total 36 tools). The respondents also assessed the impact of this commitment on the processes of dynamization of their [CA]. The research aimed at determining what level of awareness/knowledge [K] concerning the requirements of Industry 4.0 the respondents have and whether it is reflected in their activity [A] in implementing and using Industry 4.0 tools. The comparison was to allow the determination of the degree of preparedness of the analyzed companies to create [CA 4.0] and compete effectively using 11 groups of Industry 4.0.tools [CI 4.0].

The second stage of research was illustrate the level of importance of the analyzed companies' preparedness in the area of V\&DX, which is the combination of Vertical/Horizontal Software Integration \& Industrial Internet of Things, Internet of Services, i.e. 2 out of 11 earlier presented areas. The research consisted of a CATI study carried out with the use of an original survey questionnaire on a total sample of $\mathrm{N}=120$ Polish SMEs companies. 


\section{Results and discussions}

The analysis of the 5 companies selected for the pilot study in terms of their preparedness for Industry 4.0 in 11 key areas indicates that the respondents generally feel the positive impact of carried out deployments on the dynamization of their [CA].

Table 2. Preparedness to compete in the age of Industry 4.0 - pilot group evaluation

\begin{tabular}{|c|c|c|c|c|c|c|c|c|}
\hline \multirow{3}{*}{$\begin{array}{l}\text { Areas important in the } \\
\text { age of Industry } 4.0\end{array}$} & \multicolumn{2}{|c|}{ Step $1(\mathrm{~K})$} & \multicolumn{2}{|c|}{ Step 2 (A) } & \multicolumn{2}{|c|}{ Step 3 (CA 4.0) } & \multicolumn{2}{|c|}{ Step 4 (CI 4.0) } \\
\hline & \multicolumn{2}{|c|}{$\begin{array}{l}\text { Awareness of the } \\
\text { impact of the area on } \\
\text { the dynamization of a } \\
\text { CA in the age of } 4.0 \\
\text { (ability to assess the } \\
\text { impact) } N=5\end{array}$} & \multicolumn{2}{|c|}{$\begin{array}{l}\text { Activity in the use } \\
\text { of Industry } 4.0 \\
\text { tools } \mathrm{N}=5 \\
\text { (degree of } \\
\text { implementation) }\end{array}$} & \multirow{2}{*}{\multicolumn{2}{|c|}{$\begin{array}{l}\text { Preparedness for } \\
\text { CA } 4.0 \\
\text { (number of tools } \\
\text { implemented at the } \\
\text { high and very high } \\
\text { level - average for } \mathrm{N}=5 \\
\text { above } 3.5 \text { (number of } \\
\text { tools in the module) }\end{array}$}} & \multicolumn{2}{|c|}{$\begin{array}{l}\text { Preparedness of } N=5 \text { to compete } \\
\text { in the age of Industry } 4.0\end{array}$} \\
\hline & $\begin{array}{c}\mathbf{K}^{2} \\
(-2 \div+2)\end{array}$ & $\begin{array}{l}\text { Impact } \\
\text { assessment }\end{array}$ & $\begin{array}{c}A^{3} \\
(0 \div 5)\end{array}$ & $\begin{array}{l}\begin{array}{c}\text { Degree } \\
\text { of } \\
\text { impleme } \\
\text { ntation }\end{array} \\
\end{array}$ & & & $\begin{array}{c}\text { Use of module } \\
\text { CI } 4.0^{4} \\
\text { possibilities } \\
(\%)\end{array}$ & $\begin{array}{l}\text { Preparedness } \\
\text { for Industry } 4.0\end{array}$ \\
\hline $\begin{array}{c}\text { Automatization } \\
\text { Autonomous } \\
\text { Robots } \\
\end{array}$ & 0.6 & $\begin{array}{c}\text { weak } \\
\text { stimulator }\end{array}$ & 1.7 & low & $1 / 6$ & weak & 34 & mediocre \\
\hline Simulations & 0.4 & $\begin{array}{c}\text { weak } \\
\text { stimulator }\end{array}$ & 2.7 & $\begin{array}{c}\text { medioc } \\
\text { re }\end{array}$ & $0 / 3$ & $\begin{array}{c}\text { lack / } \\
\text { none }\end{array}$ & 53 & quite good \\
\hline $\begin{array}{c}\text { Vertical/ Horizontal } \\
\text { Software } \\
\text { Integration }\end{array}$ & 0.7 & $\begin{array}{l}\text { weak } \\
\text { stimulator }\end{array}$ & 2.3 & low & $0 / 5$ & $\begin{array}{l}\text { lack / } \\
\text { none }\end{array}$ & 23 & weak \\
\hline $\begin{array}{c}\text { Industrial Internet } \\
\text { of Things; Internet } \\
\text { of Services }\end{array}$ & 0.5 & $\begin{array}{l}\text { weak } \\
\text { stimulator }\end{array}$ & 1.0 & $\begin{array}{l}\text { very } \\
\text { low }\end{array}$ & $0 / 4$ & $\begin{array}{c}\text { lack / } \\
\text { none }\end{array}$ & 20 & weak \\
\hline Cybersecurity & 0.8 & $\begin{array}{c}\text { weak } \\
\text { stimulator }\end{array}$ & 3.0 & $\begin{array}{c}\text { medioc } \\
\text { re }\end{array}$ & $2 / 4$ & mediocre & 60 & good \\
\hline Cloud & 0.2 & $\begin{array}{c}\text { weak } \\
\text { stimulator }\end{array}$ & 1.0 & $\begin{array}{l}\text { very } \\
\text { low }\end{array}$ & $0 / 4$ & $\begin{array}{l}\text { lack / } \\
\text { none }\end{array}$ & 21 & weak \\
\hline $\begin{array}{l}\text { Augmented and } \\
\text { Virtual Reality }\end{array}$ & -0.2 & $\begin{array}{c}\text { weak } \\
\text { inhibitor }\end{array}$ & 0 & $\begin{array}{c}\text { lack / } \\
\text { none }\end{array}$ & $0 / 1$ & $\begin{array}{c}\text { lack / } \\
\text { none }\end{array}$ & 0 & lack / none \\
\hline $\begin{array}{l}\text { Big Data and } \\
\text { analytics }\end{array}$ & 0.5 & $\begin{array}{c}\text { weak } \\
\text { stimulator }\end{array}$ & 2.5 & $\begin{array}{l}\text { medioc } \\
\text { re }\end{array}$ & $0 / 3$ & $\begin{array}{c}\text { lack / } \\
\text { none }\end{array}$ & 49 & quite good \\
\hline Digital Twin & 0.8 & $\begin{array}{c}\text { weak } \\
\text { stimulator }\end{array}$ & 1.4 & $\begin{array}{l}\text { very } \\
\text { low }\end{array}$ & $0 / 1$ & $\begin{array}{l}\text { lack / } \\
\text { none }\end{array}$ & 28 & weak \\
\hline Mass Customization & 1.1 & $\begin{array}{l}\text { medium } \\
\text { stimulator }\end{array}$ & 2.8 & $\begin{array}{c}\text { medioc } \\
\text { re }\end{array}$ & $0 / 2$ & $\begin{array}{c}\text { lack / } \\
\text { none }\end{array}$ & 56 & quite good \\
\hline $\begin{array}{c}\text { Artificial } \\
\text { Intelligence; Neural } \\
\text { networks }\end{array}$ & -0.1 & $\begin{array}{c}\text { weak } \\
\text { inhibitor }\end{array}$ & 0.4 & $\begin{array}{l}\text { lack / } \\
\text { none }\end{array}$ & $0 / 3$ & $\begin{array}{l}\text { lack / } \\
\text { none }\end{array}$ & 8 & very weak \\
\hline Generally $N=5$ & positive & $\begin{array}{l}\text { weak } \\
\text { stimulator }\end{array}$ & $\begin{array}{l}\text { very l } \\
\text { imple } \\
\end{array}$ & $\begin{array}{l}\text { o degree } \\
\text { entation }\end{array}$ & prep & $\begin{array}{l}\text { k of } \\
\text { dness for } \\
4.0\end{array}$ & $\begin{array}{c}32 \% \\
\text { possibilities } \\
\text { used } \\
\end{array}$ & mediocre \\
\hline
\end{tabular}

If $\mathrm{K}$ (average) $=<-2$; - $1>$ factor is a strong inhibitor of dynamization of the company's CA; $<-0.9 ;-0.1>$ factor is a weak inhibitor $<0>$ neutral factor; $<0.1 ; 0.9>$ factor is a weak stimulator $<1 ; 2>$ factor is a strong stimulator

If A(average) $=<0 ; 0.4>$ lack of application; $<0.5 ; 1.4>$ very low degree of implementation; $<1.5 ; 2.4>$ low degree $<2.5 ; 3.4>$ average degree; $<3.5 ; 4.4>$ high; $<4.5 ; 5>$ very high degree of implementation.

If CI (average) $=0 \div 14 \%$ use of possibilities and very weak preparedness; $15 \div 29 \%$ weak; $30 \div 44 \%$ average; $45 \div 59 \%$ quite good; $60 \div 74 \%$ good; $75 \div 89 \%$ more than good; $90 \div 100 \%$ very good preparedness.

Source: The authors' own research. 
The respondents value most highly the solutions in the areas of (see Table 2, Step 1):

- "Mass Customization" [K=1.1], i.e. modularity of products and systems supporting Mass Customization (the offer adjusted to individual customers' needs),

- "Cybersecurity" [K=0,8], i.e. security of data collected in databases and systems, real-time data backup, antivirus security and antispyware developed in cooperation with external experts,

- $\quad$ "Digital Twin" [K=0.8], i.e. the possession and systematic use of the reference models for adjustment (calibration)of implemented processes.

Although of only average strength, they are stimulants of processes of dynamization of the analyzed companies' CA. This is confirmed by data referring to their activity in the use of Industry 4.0 tools. The first two areas belong to the group implemented by the surveyed companies at least at the average level [respectively $A=2.8 ; A=3.0$ ]. They are complemented by, less appreciated, but still implemented tools in the areas of "Simulations" [A=2.7] as well as "Big Data and Analytics" [A=2.5]. They include solutions in the field of computer software for product modeling and process simulations, as well as techniques related to real-time collection of data on processes, e.g.: the use of databases for real-time decision-making.

The respondents value the least the usefulness in their own activity concerning solutions in the areas of "Augmented and Virtual Reality" [K=-0.2] as well as "Artificial Intelligence and Neural Networks" [K=-0.1]. The first are associated with the use of augmented reality tools, e.g.: 3D glasses displaying the instructions imposed on the observed object (in the course of training or repair work). The latter are associated with smart processes, i.e. using artificial intelligence machines (learning on the basis of historical data, etc.), smart supply chains and smart products. They are considered to be inhibitors. The level of their implementation is low, which also causes a slowdown of dynamization of the surveyed companies' [CA]. This is probably due to the fact that the respondents' activity in this regard is practically non-existent (see Table 2, Step 2).

Summing up the respondents' activity in terms of the use of tools specific to Industry 4.0, it should be emphasized that they are most commonly applied in the areas of "Cybersecurity" [A=3.0], "Mass Customization" [A=2.8], "Simulations" $[\mathrm{A}=2.7]$ as well as "Big Data and Analytics"[A=2.5]. Trace activity is reported in the areas of "Augmented and Virtual Reality" $[A=0]$, "Artificial Intelligence and Neural Networks" $[A=0.4]$, and very low in the areas of" Industrial Internet of Things and Internet of Services" [A=1.0], "Cloud" $[A=1.0]$ and "Digital Twin" [A=1.4].

The comparison of data on the respondents' awareness concerning the importance of Industry 4.0 tools for their competitiveness [K] and their activity in the implementation of these tools $[\mathrm{A}]$ allowed to identify the areas in which companies are best prepared for the creation of [CA 4.0]. Unfortunately, for the moment, the average level of preparedness for the creation of [CA 4.0] among the respondents is observed only in the area of "Cybersecurity". (see: Table2, Step 3). Out of 4 Industry 4.0 tools analyzed in this area, high or very high level of 2 of them was recorded. This result concerned "real-time data backup" $[\mathrm{A}=3.6]$ and "standard antivirus security" $[\mathrm{A}=3.6]$. These are the tools critical today to the safe functioning in the market, hence such a high level of involvement in their exploitation is not surprising. An equally high level of implementation activity was recorded in 
"automated machines and production equipment" [A=3.8], and tools in the area of "Automatization, Autonomous Robots". This entire section ranked slightly lower, out of 6 analyzed tools of Industry 4.0 only 1 deployment achieved a high level. Similarly to "Cybersecurity" tools, also these tools, associated with modern production solutions, are among the most needed investments in today's organizations. It can be therefore concluded that the respondents quite consciously select areas of their activity in terms of Industry 4.0 solutions. At the beginning of their road towards 4.0, they tend to choose basic solutions, but at the same time they are gradually exploring the possibilities of involvement in other, more technologically advanced and less familiar areas related to Industry 4.0. As a result, out of 11 analyzed areas, in 3 of them the surveyed enterprises ranked their preparedness to compete in the age of Industry 4.0 as "very good" (Mass Customization, Simulations, Big Data and Analytics), or "good" (Cybersecurity). Unfortunately, in the area of "Augmented and Virtual Reality", the level of the respondents' preparedness to compete in the age of Industry 4.0 seems to be imperceptible.

On the basis of the respondents' assessment concerning the use of possibilities offered by 36 tools in 11 areas typical of Industry 4.0, it can be said that currently (the year 2017) they are exploiting only $32 \%$ of the tools, which indicates an average level of preparedness of the respondents for Industry 4.0 (see Table 2, Step 4, CI 4.0). The highest level of use of possibilities offered by Industry 4.0 tools was recorded for "Cybersecurity"60\%, "Mass Customization"- 56\% and "Simulations"-53\%. The lowest level of use of these possibilities can be seen in the areas of "Augmented and Virtual Reality - $0 \%$ as well as "Artificial Intelligence and Neural Networks"- 8\%.

The accuracy of the above-presented results is confirmed by the findings of the nationwide study called Smart Industry Polska (Poland) 2017 (Nowicka/Kantar Millward Brown. 2017), i.e. the research carried out on a nationwide sample of industrial enterprises (SMEs) conducting manufacturing activities in Poland which included 251 SMEs. See Figures 2 and 3.

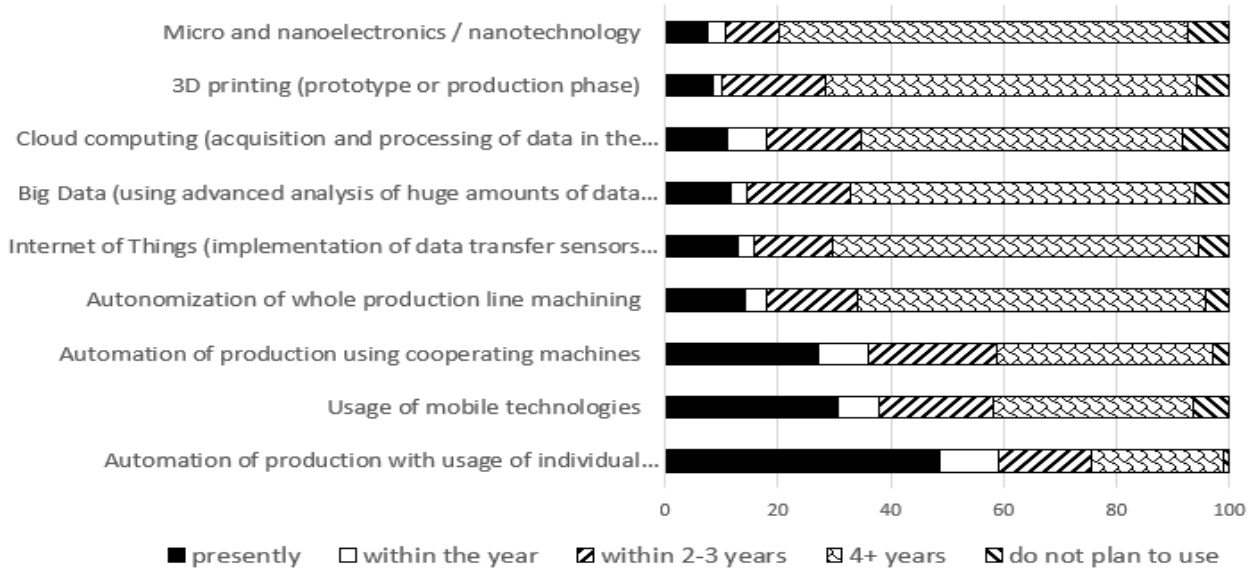

Figure 2. The use of Industry 4.0 tools - presently and in the future

Source: own elaboration based on Nowicka/Kantar Millward Brown. 2017. SMART INDUSTRY POLSKA 2017. 

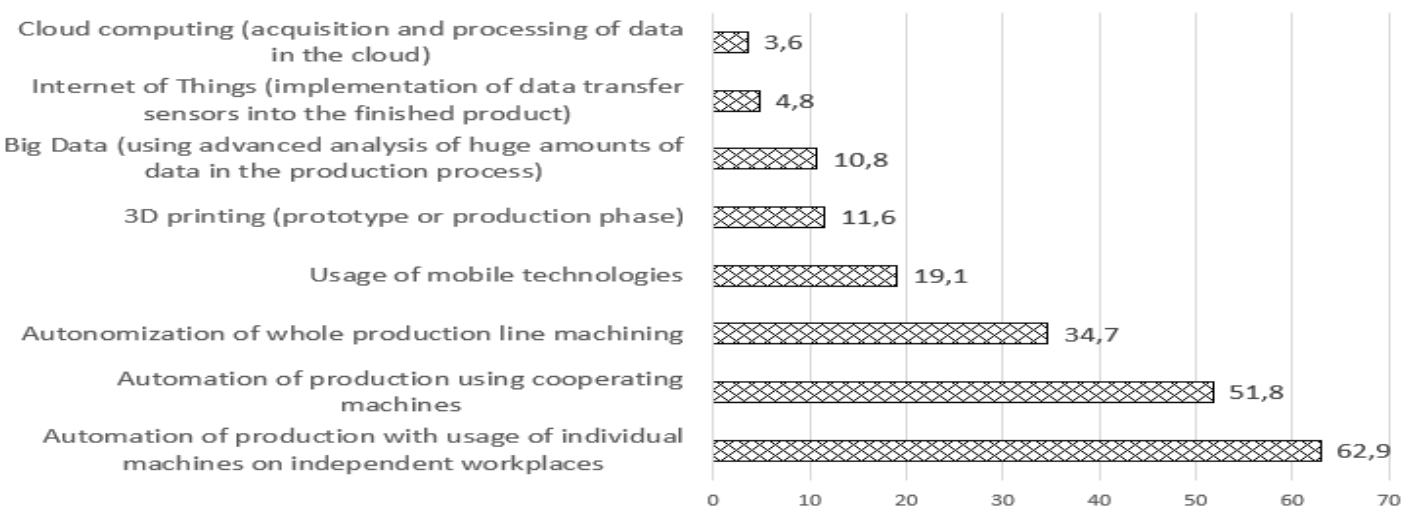

Figure 3. Industry 4.0. - technologies with the highest impact on competitiveness Source: own elaboration based on Nowicka/Kantar Millward Brown. 2017. SMART INDUSTRY POLSKA 2017.

The results of the pilot study clearly indicate that the examined companies are rather at the beginning of the road connected with the development of the tools generally considered to play an important role in creating [CA 4.0]. The solutions related to automation of production and use of mobile technology are of the greatest interest. A significant number of the analyzed companies are already investing in the development of these tools or planning to do so in a period of not more than 3 years.

Slightly different opinions are provided by representatives of Polish micro and small enterprises -the respondents of the second stage of the research procedure (CATI).They are declaring an average level of the use of [V\&DX]. These conclusions are based on the results showing the levels of: activity [Av\&Dx], knowledge [Kv\&DX], competitive advantages [CAv\&Dx] as well as the possibilities of dynamization of competitiveness [CIv\&DX] connected with the area of [V\&DX]. The results summarized in the table below indicate that the respondents are moderately active on the virtual plane of operation [Av\&DX A 0.93 ], and this activity is the greater the higher the level of knowledge concerning the possibilities of the use of virtualization tools and the associated benefits $\left[\mathrm{A}_{\mathrm{V} \& \mathrm{DX} \mathrm{B}}=1.58\right]$.

Table 3. V\&DX and competitiveness

\begin{tabular}{|l|c|c|c|c|c|}
\cline { 5 - 7 } \multicolumn{2}{l|}{} & KV\&DX & Av\&DX & CAv\&DX & CIV\&DX \\
\hline Analyzed SMEs (N = 120) & A & 0.50 & 0.93 & 0.87 & 0.27 \\
\hline SMEs with a high level of knowledge of V\&DX (N = 80) & B & 1.32 & 1.58 & 1.24 & 0.56 \\
\hline SMEs with a low level of knowledge of V\&DX (N = 40) & C & -1.1 & 0.03 & 0.3 & 0 \\
\hline
\end{tabular}

*Possible Values <-2,2>

Source: The authors' own research.

The assessment of the level of knowledge about V\&DX provides a less favorable picture, as coefficient [ $\left.\mathrm{K}_{V \& D X} \mathrm{~A}=0.50\right]$. The level of knowledge significantly differentiates the assessment of the level of a given company's competitiveness and the expected degree of its improvement. In both cases, the higher the level of virtualization knowledge, and 
consequently the level of activity, the higher the assessment of these parameters - [CAV\&DXA $=0.87$ ] and [CIV\&DX A $=0.27]$, while $\left[C_{V} \& D X B=1.24\right]$ and $\left[C_{V \& D X B}=0.56\right]$. See the graphical illustration - Figure 4.

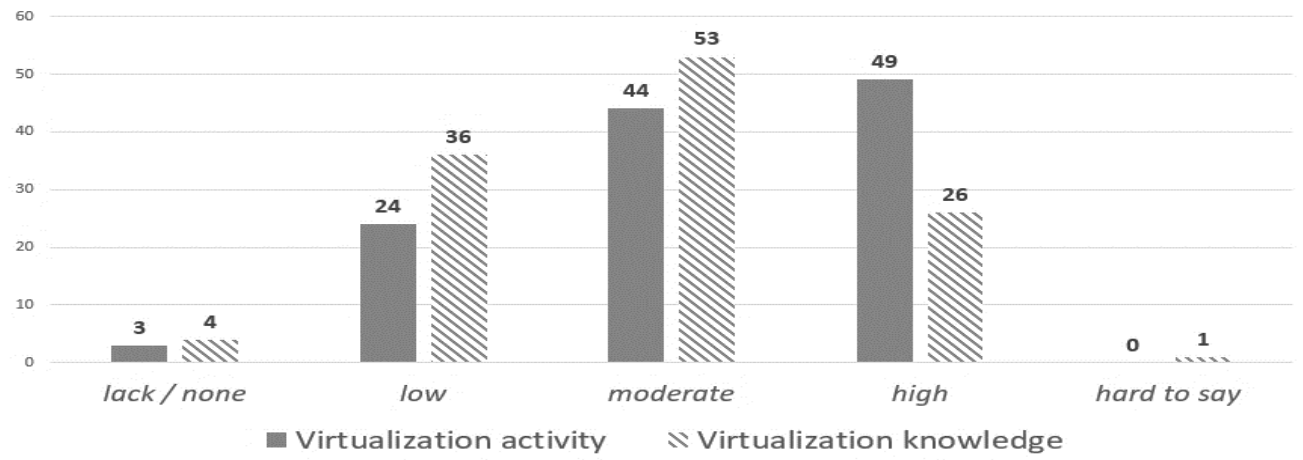

PICBE $\mid 20$

Figure 4. V\&DX - levels of knowledge, activity and competitiveness dynamization $(\mathrm{N}=120)$

Source: The authors' own research.

The respondents were also asked to specify whether, in their opinion, the use of [V\&DX] tools in the future would allow the company to perform better than today in the fields of: promoting the company's business activity [a]; acquisition of new customers [b]; retaining existing customers [c]; defending against the impact of competitors [d]; acquisition of partners and allies [e].

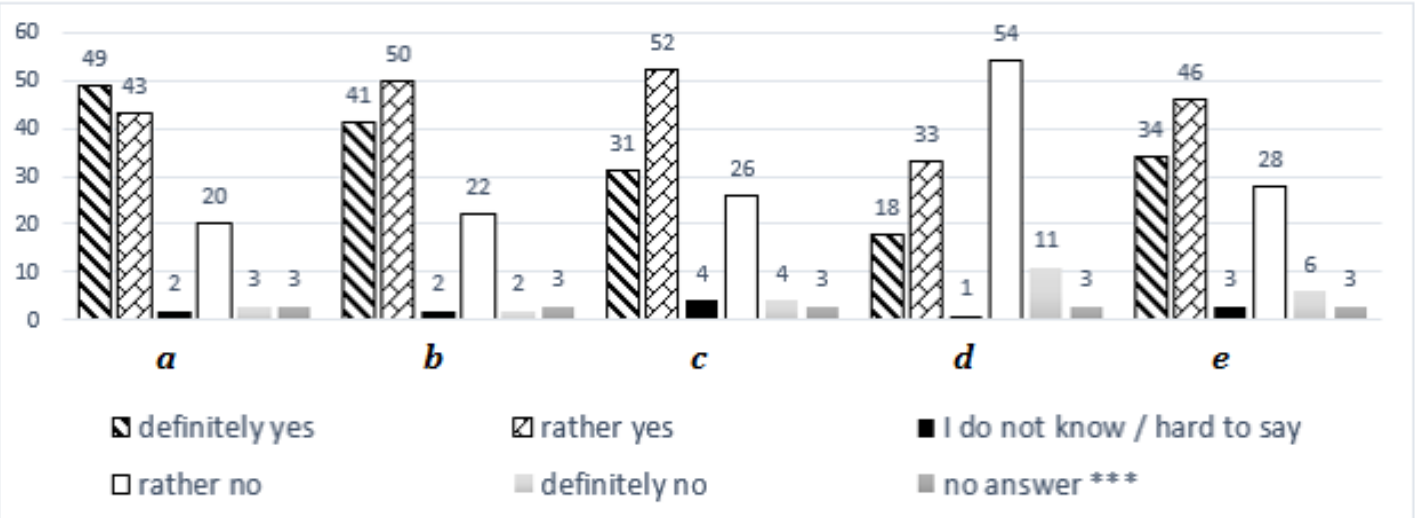

Figure 5. The use of V\&DX and raising effectiveness in specific areas $(\mathrm{N}=120)$

Source: The authors' own research.

The above-presented figure indicates that, according to the respondents, having well-established knowledge and a high level of activity in the area of [V\&DX] contributes to the greatest degree to increasing effectiveness of promoting the company's business activity [a], and to the least degree to increasing effectiveness of activities connected with defending the company against the impact of its market competitors [d].

The representatives of the analyzed SMEs were also asked to specify how the use of V\&DX tools allowed them to shape their competitiveness. 


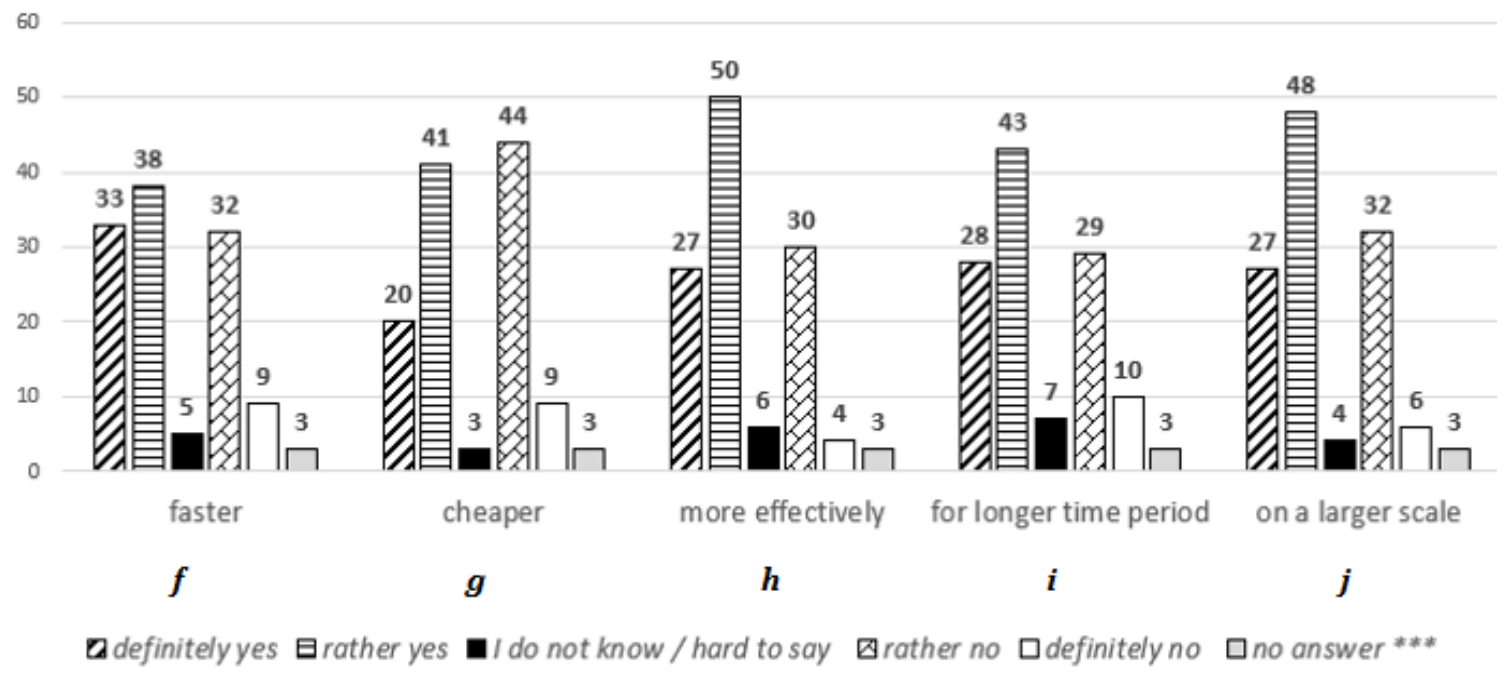

PICBE | 21

Figure 6. The use of V\&DX and specific parameters of competitive position of the company $(\mathrm{N}=120)$

Source: The authors' own research.

According to the respondents, having well-established knowledge and a high level of activity in the area of [V\&DX] has the strongest impact (ex a equo) on the possibility of increasing the pace of building a competitive advantage [f] and raising its effectiveness [h], to a slightly lesser degree on the scale (range) of its impact [j], and to the least degree on cost intensity [g] (see Figure 6).

\section{Conclusion}

The presented results of the empirical research provide evidence for positive verification of hypotheses formulated in the research process. The findings of the research conducted indicate that companies operating in Poland, although increasingly aware of benefits of the application of modern solutions, still have a relatively low level of knowledge concerning requirements of the age of Industry 4.0 [K]. This results in their low activity [A] in terms of the use of tools specific to this age. They lack preparedness to effectively create [C.A. 4.0] as well as to dynamize their competitiveness [C.I. 4.0].

The respondents feel relatively best prepared in: "Cybersecurity" [CI=60\%], "Mass Customization" [CI=56\%], and "Simulations" [CI=53\%]. It should be also noted that there is significant diversity of results concerning preparedness of companies for [DX] and creating a [CA] in the age of Industry 4.0. depending on what size the analyzed entities were and which area was examined. Analyzing the SME sector in the area of [V\&DX], it can be seen that micro enterprises declare relatively higher than in other groups levels [KV\&DX] and [Av\&Dx]. This is probably due to the fact that very often they are subcontractors for large organizations, often corporations. Thus, on the one hand, they are compelled to use modern [DX] solutions, but on the other hand, they have the possibility of learning and acquiring knowledge on the use of this type of tools in an easier manner.

According to the surveyed Polish SMEs, the degree of their preparedness to compete in the realities of Industry 4.0 constitutes a symbolic basis for the development of [C.A. 4.0] 
and [C.I. 4.0]. The level of their knowledge and activity in this area also plays a role in enhancing their effectiveness in: promoting activities, acquiring new and maintaining existing customers, partners and allies, as well as defending against competitors.

Due to the fact that the CATI study in the analyzed SMEs was limited to [V\&DX], it is necessary to continue studies in the other areas creating competitiveness in the age of Industry 4.0.

PICBE $\mid 22$

\section{References}

(2013) "So what is competitive advantage?: We know we need it but not how to define it", Strategic Direction, Vol. 29 Issue: 9, pp.6-8, https://doi.org/10.1108/SD-08-20130049.

(2016) "Catch me if you can!: Creating competitive advantage", Strategic Direction, Vol. 32 Issue: 4, pp.24-26, https://doi.org/10.1108/SD-01-2016-0005.

Adamik, A. (2008). Competitive Advantage Based on Cooperation. A Series of Monographs of Technical University of Lodz. No. 1819.

Adamik, A. (2016). The mechanism of building competitiveness through strategic partnering. Management, 20(1), 292-309.

Adamik, A., Flaszewska S. (2015). The positive potential of the organization and knowledge partnering. Journal of Positive Management. 6(3), 29-41. DOI 10.12775/JPM.2015.014.

Audretdch, D. B., Link, A. N., Walshok M. (eds.). (2015). The Oxford Handbook of Local Competitiveness. Oxford University Press. New York.

Barney, J., Hesterly, W. (2006). Strategic management and competitive advantage. Concepts and cases. Pearson Education. New Jersey.

Bellgran, M., Bruch, J., Rösiö, C., Wiktorsson, M. (2013). Decision support for production localization: Process. activities and localization factors. Postprint from the 20th International EurOMA Conference. Dublin.

Bender, M., Willmott, P. (2017). Digital Reinvention. McKinsey \& Company.

Berman, S.J., Bell, R./IBM. (2011). Digital transformation Creating new business models where digital meets physical. IBM Global Services. New York, USA.

Brakman, S., Garretsen, H. (2005). Location and Competition. Routledge Taylor \& Francis Group. New York.

Bughin, J., LaBerge, L., Mellbye, A.(2017). The case for digital reinvention. McKinsey Quarterly. Seattle/Washington. USA.

Chakravorti ,B. (2010). Finding competitive advantage in adversity. Harvard Business Review. 88(11),102-108.

Cifranic, M. (2016). Localization factors in decision making of location of selected enterprises. The agrifood value chain: challenges for natural resources management and society. Slovak University of Agriculture. Nitra.

CISCO (2014). Cisco Global Cloud Index 2013-2018. Cisco Systems Inc., San Jose.

Dubois, D. (2017). A Framework for Driving Digital Transformation, INSEAD/European Business Review. 
Ferrier, W.J., Wiltbank, R. (2010). Value from Gestalt: How Sequences of Competitive Actions Create Advantage for Firms In Nascent Markets Violina Rindova. Strategic Management Journal. 31(13), 1474-1497.

Garrison, G., Wakefield, R.L., Kim, S. (2015). The effects of IT capabilities and delivery model on cloud computing success and firm performance for cloud supported processes and operations. "International Journal of Information Management". 35(4), 377-393.

Gaub, H. (2016). Customization of mass-produced parts by combining injection molding and additive manufacturing with Industry 4.0 technologies. Reinforced Plastics. 60(6), 401-404.

Geissbauer, R., Vedso, J., Schrauf, S. (2016). Industry 4.0: Building the digital enterprise: 2016 Global Industry 4.0 Survey. PwC (PricewaterhouseCoopers).

Grossman, R. (2016). The Industries That Are Being Disrupted the Most by Digital. Harvard Business Review. Harvard Business Publishing. Boston. USA.

Hermann, M., Pentek, T., Otto B.(2015). Design Principles for Industries 4.0 Scenarios: A Literature Review Working Paper No. 01/2015. Available at: http://www.thiagobranquinho.com/wp-content/uploads/2016/11/DesignPrinciples-for-Industrie4_0-Scenarios.pdf.

Kiron, D., Shockley R. (2011). Creating Business Value with Analytics MIT. Sloan Management Review. September 15.

McKinsey Digital 2015. Industry 4.0 How to navigate digitization of the manufacturing sector.

Parsons, R. A. (2015). The impact of age on innovation. Management Research Review. 38 (4), 404-420.

Porter, M.E. (2008). Competitive advantage. creating and sustaining superior performance. The Free Press.

Pupavac, D., Obradovic, S., Baburić, M. (2013). Choice of location for retail businesses. Business Logistics in Modern Management. Croatia.

Qin, J., Liu Y., Grosvenor, R.(2016). A Categorical Framework of Manufacturing for Industry 4.0 and Beyond. Procedia CIRP 52. pp.173-178.

Rao, C.B. (2016). Competitive strategy. A contemporary Retake. Leader Crest Academy. Notion Press.

Rüßmann, M., Lorenz, M., Gerbert, P., Waldner, M., Justus, J. Engel, P., Harnisch, M. (2015). Industry 4.0 - The Future of Productivity and Growth in Manufacturing Industries. The Boston Consulting Group. Boston. USA.

Salem, K.A.F.M.(2016). The value of strategy and flexibility in new product development. The impact on performance. Journal of Enterprise Information Management. 29(4), 525-548.

Soon, L. N. (2016). Managing change and risk in the age of digital transformation. The digital journey of financial institutions in ASEAN. EY (Ernst \& Young).

Trappey, A.J.C., Trappey, Ch.V., Govindarajan, U.H., Chuang, A.C., Sun, J.J. (2016). A review of essential standards and patent landscapes for the Internet of Things: A key enabler for Industry 4.0. Advanced Engineering Informatics. 
Tsangaris, A. (2012). Virtualization Market and VMware Success. VMware. on-line: http://www1.performance.gr/files/presentations/03.VirtualizationMarket_A.Tsang aris.pdf. [online access: 28.11.2017].

Vecchiato, R. (2015). Strategic planning and organizational flexibility in turbulent environments. Foresight. 17(3), 257-273.

Weyer, S., Schmitt M., Ohmer M., Goreck D. (2015). Towards Industry 4.0 - Standardization

PICBE | 24 as the crucial challenge for highly modular multi-vendor production systems. IFACPapers On Line 48(3), 579-584. 